\title{
Driving innovation management to create shared value and sustainable growth
}

\author{
Mercedes Rubio-Andrés ${ }^{1}$ (D) $M^{a}$ del Mar Ramos-González ${ }^{2}$ (D) \\ Miguel Ángel Sastre-Castillo ${ }^{3,4}$
}

Received: 28 May 2021 / Accepted: 1 January 2022 / Published online: 17 January 2022

(c) The Author(s) 2022

\begin{abstract}
Creating shared value (CSV) is an opportunity for sustainable growth for small and medium-sized enterprises that entails jointly achieving both social and business value. Currently there are few practical approaches that underpin the importance of CSV and that explore which variables have a positive impact on SMEs. Our paper seeks to shed light on this issue by proposing a measuring and governance model to assess the benefits of CSV in SMEs, using a sample of Spanish SMEs for the empirical analysis, and PLS-SEM as the analysis technique. We first highlight innovation management as a key variable for CSV. It is essential to take innovative strategic decisions to identify which initiatives generate shared value. Our findings confirm that innovative business management helps cultural transformation processes to be implemented with high shared value, which is a source of opportunities in a global economy and, consequently, lead to sustainable growth. Secondly, we aim to highlight how innovative firms enhance their reputation, which in turn has an impact on the creation of social and business value. We also find that if SMEs emphasise social value, they boost the creation of business value, with their role as mediators proving to be vital. We present a strategic management model based on variables such as innovation management, social value and reputation, due to their impact on business value.
\end{abstract}

Keywords Innovation management $\cdot$ Social value $\cdot$ Shared value $\cdot$ Reputation . Business value $\cdot$ SMEs $\cdot$ Sustainable growth

Mercedes Rubio-Andrés marubi24@ucm.es

Extended author information available on the last page of the article 
Mathematics Subject Classification 62P25 · 91C99

\section{Introduction}

Creating shared value (CSV) is currently one of the most topical and interesting concepts in the field of business management. As precursors of CSV, Prahalad and Ramaswamy (2004) see this new formula as a chance for firms to create value and to develop fresh sources of competitive advantage. Later, Porter and Kramer (2011) posit CSV as a new purpose for organisations, with cultural transformation playing a key part in the accomplishment thereof. The creation of shared value involves, in turn, achieving social value and business value. Nevertheless, we believe that if organisations place the emphasis on social value, this will then lead to the creation of business value. Firms who adopt a CSV strategy will be those who succeed; in the theoretical framework, we explore in depth how shared value offers the greatest opportunity for growth currently open to organisations in a global economy (Porter and Kramer 2011).

Our research focuses on the key variables required for small and medium-sized enterprises (SMEs) to achieve CSV and sustainable growth. We highlight the role played by innovation management, and in the empirical analysis we seek to validate its role vis-à-vis improving CSV. Innovation is one of the most important competitive strategies for small and large enterprises (Kaufmann and Todtling 2002). Therefore, from a financial perspective, stimulating innovation in the field of SMEs poses a major challenge (Keizer et al. 2002). SMEs display specific features compared to large businesses, which gives rise to a different type of business management innovation (BMI) model (Clauss et al. 2020) since the former are more flexible than large firms (Gelinas and Bigras 2004). Despite the importance of SMEs in western economies, few studies have addressed SMEs' business model (Lee et al. 2012), their strategies (Lindgren 2012) or what effect they have on performance (Guo et al. 2017).

Innovation is the implementation of a new or vastly enhanced product or process, marketing method or organisation, business practices, workplace organisation or improved overseas relations (OECD 2005). It is also the key to business survival, performance and growth in today's turbulent business environments (Brand et al. 2019). Previous studies have developed techniques to measure innovation related to the required products and processes (Leenders and Wierema 2002; Burdon et al. 2015). It should be pointed out that innovations need to be successfully introduced into the market or to be put into practice if they are to achieve an economic impact; in other words, they need to go beyond the mere invention stage (OECD 2005: 17).

As a result, innovation proves key when it comes to taking strategic decisions that will enable initiatives that generate shared value to be identified. Innovative business management allows for the creation of processes of cultural transformation that are a source of opportunity in a global economy and, as a result, of sustainable growth (Ramos-González et al. 2021). 
As a differentiating and innovative element in our model compared to previous models, reputation plays a key role. Firstly, it has a direct influence on CSV, since a solid reputation generates greater client satisfaction and leads to improvements in the firm itself, in addition to having a positive impact on financial performance. Secondly, reputation plays a mediating role between innovation management and CSV. In this regard, SMEs that adopt innovation management enhance their reputation whilst at the same time generating sustainable value. In the theoretical framework, we explore this relation in greater depth.

Despite the fact that SMEs have a significant weight in almost all economies, research into management innovation tends to centre on large firms (Hemingway and Maclagan 2004; Melé et al. 2006; Jamali and Mirshak 2006). SMEs constitute 99\% of companies in the EU, provide two-thirds of private sector jobs and contribute to over half of the total added value created by businesses in the EU (Fact Sheets on the European Union 2021). Cases of major corporations in terms of CSV have also been the most widely addressed in the literature even though it is small firms that best perform the key role of CSV related to cluster development and stakeholder projects (Corazza et al. 2017). Following a similar line of argument, Moon et al. (2011) claim that certain unmet needs in society give rise to opportunities for CSV, given the attention that is focused on disadvantaged communities and developing countries, where SMEs are able to achieve this goal more easily thanks to their greater local proximity.

Clauss et al. (2020) recently highlighted the need to include SMEs in studies on BMI, given that previous research has focused on analysing innovation in the business model of large companies that have an international impact. As a result, we believe that it is interesting and innovative to focus our empirical study on SMEs, creating an exclusive and complex model with four latent variables. Innovation management as the exogenous variable and the creation of shared value has been split into the two dimensions of which it is made up, according to the literature reviewed-social value and business value - with the latter being the main endogenous variable. The reason behind this split is that it enables the effects to be assessed independently; specifically, what effect social value has on business value. In addition, the variable reputation has been included in the model due to its importance at the present time as well as its link to the variables mentioned.

As research questions, we ask whether: (1) SMEs who engage in innovation management enhance the creation of shared value and reputation, (2) achieving reputation thanks to innovation can drive CSV in its two dimensions, (3) reputation and social value have direct effects on business value, (4) social value and reputation have any mediating effect amongst the model's main variables.

In order to carry out this study, we gathered information from 1,136 Spanish SMEs who employ between six and 250 workers from the four main sectors (industry, construction, retail, and service), assuming a sampling error of $2.9 \%$. We use PLS-SEM, and posit hypotheses linked to the research questions. Prominent amongst the main conclusions, we highlight the importance of innovation management vis-à-vis improving CSV and reputation, as well as the mediating role of social value to achieve business value. In sum, if SMEs wish to improve their CSV due to 
both the economic and non-economic benefits these entail, they should seek to adopt innovation management that will enhance their reputation.

\section{Conceptual framework and hypotheses}

\subsection{Shared value creation}

The contributions made by Porter and Kramer (2011) offer a benchmark highlighting the links between business and society. Shared value is defined through operational policies and practices that improve a firm's competitiveness as well as helping to enhance economic and social conditions. Both economic and social progress should focus on creating value. CSV is based on the idea that the company's goal should be redefined. Thompson and MacMillan (2010) define it as enriching a part of society through specific improvements that are monitored and measured in one or more social dimensions.

In contrast to the conventional idea that maximising economic value generates less social value (see Friedman 1970), current thinking defends the notion that the firm can realise the two values at the same time (Salas Fumás 2011). The CSV approach seeks to overcome the apparent conflict between the interests of business and society, based on the notion that there are numerous opportunities for firms to obtain a profit whilst at the same time creating value for society. In this regard, if firms are able to create economic value by creating social value, the question would not concern whether these firms achieve better financial results but rather whether they have embraced the principles of shared value.

The problem arises when the vision of certain firms is focused on short-term financial performance and not on the most important needs of their stakeholders that will determine long-term success. There is a need to consider a longterm horizon that takes into account the expectations of society as well as those of clients, investors, competitors, suppliers, staff and other stakeholders. For Moon et al. (2011) it is society that pressures firms to make a social contribution, generating shared value so that it not only becomes a "Good Corporation" but also a "Smart Corporation". Management is thus better placed to create shared value through a broader framework that embraces ethical norms; so-called CSV + (Gastón de los Reyes et al. 2017). One of the strengths of CSV is that managers can identify an opportunity to create economic value (a victory) and social value (two victories) based on business and social problems (Gastón de los Reyes et al. 2017). In sum, CSV explains how firms can transform their social and environmental problems into solutions that benefit everybody (Porter and Kramer 2011).

Although CSV has sparked enthusiasm amongst the business and corporate community, it has by no means been free from criticism (Corazza et al. 2017). For Crane et al. (2014), firms' economic goals are already shaped by society and, to a certain degree, it may even prove counterproductive for them to try to create a better world by seeking to reshape capitalism. For said authors, stakeholder theory is probably the oldest theory for reconceptualising the firm as a multi-purpose 
entity. At its different levels, stakeholder theory encompasses the social reality that corporations both affect and are affected by society, and that these groups are legitimately entitled to have their "say" in how firms should be run.

However, achieving both social and economic goals can be difficult for companies. If the company is responsible towards customers, the environment, and society, it often means raising prices. If competitors do not act in the same way, then selling at low prices is inevitable (Málovics et al 2008). Thus, it is difficult to act according to social value criteria since the most important factor is to sell at a low price.

Despite the controversies, the idea of linking strategic and social aspects is appealing, and indeed is even more so if the firm is able to bring together areas that were previously unconnected (Corazza et al. 2017).

With regard to the effects of CSV, Porter and Kramer (2011) highlight improved long-term competitiveness and sustainable growth through the development of its business and social conditions. In the same line, Sánchez-Hernández et al. (2017) underscore the importance of stakeholder satisfaction in terms of enhanced competitiveness.

Innovative business management allows for the creation of processes of cultural transformation that are a source of opportunity in a global economy and, as a result, of sustainable growth.

In the case of SMEs, policies based on redesigning the product, improvements in production processes and implicit interaction with local groups enhance the social conditions of the communities in which they operate whilst also boosting performance. This has been shown through empirically tested evidence for both small and medium-sized firms in all production sectors (Becerra-Vicario et al. 2020).

In our model, we address CSV in its social and financial dimensions. Academic literature has made great strides in this regard and it is now being seen as increasingly important for firms to focus their efforts on generating social value. As a result, having innovation management that puts forward transformative business initiatives proves essential. Authors such as Bouncken and Gömar (2021) have recently proposed different co-working spaces, ranging from the more traditional corporate and independent ones to the open co-working spaces related to consulting and universities that encourage internal and external cooperation. The authors' findings advocate a shift in employees' work design and routines (Bouncken and Fredrich 2016; Bouncken and Reuschl 2018).

Also linked to social value, Van Beurden and Gossling (2008) believe that this is developed in three categories: the first involves questions of social interest (Wu 2006). A second category includes action in social and environmental programmes, as well as initiatives that directly impact the firm's management and staff. A third category links corporate reputation to organisations' values and behaviour. In most of the cases studied, social value is analysed taking into account the second and third category. Our model applied to SMEs considers the two categories represented in different latent variables-social value and reputation-with the final dependent variable being business value. 


\subsection{Innovation management and shared value creation}

It is known that innovation enables firms to transfer the knowledge learnt and to offer better solutions (Maranville 1992) to satisfy new social needs and implement innovative ideas and decisions (Cegarra-Navarro et al. 2016). As a result, it is essential for firms who wish to achieve technological leadership to develop new products and services (Lumpkin and Dess 1996; Rauch et al. 2009).

Over the last few years, the concept of innovation has broadened. Entrepreneurship orientation (EO) is defined as three-dimensional management: innovative, proactive, and risk-taking (Rauch et al. 2009; Covin and Lumpkin 2011; Covin and Miller 2014). Certain organisations have developed business model innovation (BMI) as an alternative to innovation based on developing new products and services. This entails innovative management through the incorporation of original factors such as designing new workspaces and work habits that involve cultural transformation (Cheah and Ho 2019; Bouncken and Gömar 2021). In this regard, firms that follow this model seek to achieve a balance on three fronts: human resources management, efficient risk acceptance, and management of change (see Staniewski et al. 2016).

Amit and Zott (2012) highlight the importance of BMI due to its positive effects at three levels: firstly, because it allows the firm to create value, secondly because of its protecting effect against possible imitations from competitors, and finally as a powerful competitive tool. In the model we present, innovation management stands as an independent latent variable. Battaglia et al. (2014) explore how innovation in SMEs can imply the creation of new work methods, products, services, processes as well as new market opportunities that can help to create trust and support amongst stakeholders, enabling them to understand new social and economic achievements (Blakely and Aparicio 1990).

Gregory et al. (2009) show that organisational culture and work climate have a major impact on organisational efficacy by pointing firms towards innovation, modifying the attitudes of employees who recognise innovation as a key value for the firm, and boosting their level of involvement (Dulaimi and Hartmann 2006). Coworking spaces are key to achieving the efficacy mentioned, because they offer social areas as well as myriad opportunities for workers to contact one another (Capdevila 2013), encouraging creativity thanks to the sense of belonging (Fuzi 2015) and improving innovation (Greenwood et al. 2010). Compared to the traditional system, innovation management implies more advanced management in which the firm's relation with the various stakeholders is essential. In order to achieve this, it is necessary to establish platforms of active dialogue. Bouncken and Gömar (2021) highlight that such areas provide a space for social interaction and that they generate greater levels of satisfaction as well as encouraging an innovative mindset.

Business model innovation may come in a number of forms: increasing the content of the system of activities, linking activities in an original way, or making major changes that entail a new system of activity: in other words, innovation in the business model is based on content, structure and governance. In this regard, these authors recommend management that involves a systemic and holistic vision that 
sees innovation not as an isolated piece but as a key part of the business model (see Amit and Zott 2012).

Some researchers (for example, Nicholls 2008; Swanson and Di Zhang 2010; Bagnoli and Megali 2011) have identified the capacity for innovation as determinants of CSV (see Weerawardena and Mort 2006), with the capacity to innovate being a vital driver for firms' social activities, and which allows them to design social aims whilst also enabling the focus to fall on economic objectives (Bocquet et al. 2013; Clark 2000; Rasoulzadeh et al. 2013). Nevertheless, it should also be pointed out that there is a general lack of consensus concerning whether or not certain innovations have had either a positive or a negative impact on society, particularly vis-à-vis the impact on quality of life and social interaction (Acs et al. 2013).

Innovation has been analysed due to its impact on variables such as performance (Yeh-Yun Lin and Yi-Ching Chen 2007) and business growth (Christensen and Raynor 2003; Piperopoulos and Scase 2009; Vaccaro et al. 2010; Börjesson and Löfsten 2012; Szczygielski et al. 2017). The work of Jaruzelski et al. (2011) claims that firms which display cultures that are closely aligned to innovation may see their value increase by as much as $30 \%$ compared to their rivals.

According to Hirshleifer et al. (2013) innovation is a strong predictor of future company performance and plays a major role in explaining operating performance, market profitability and stock returns (share prices). Soufre and GopalakrishnaRemani (2019) suggest that worker involvement and training (indicators of company innovation) have a positive effect on social performance which then leads to financial performance. In this way, both in its social as well as economic dimensions $\mathrm{CSV}$ is a goal that is achieved through innovation management.

For the first dimension of CSV, business value, we use the procedure of Baron and Kenny (1986) to test the direct relation between innovation management and business value, and which should be validated in an initial model only with the two variables.

As a first hypothesis, we propose:

Hypothesis 1a Innovation management has a significant and positive influence on business value in SMEs.

For the second dimension, the impact of innovation management is also assessed, although this is carried out in the causal model due to the mediating role of social value that is subsequently studied.

We now propose the following direct hypothesis:

Hypothesis 1b Innovation management significantly and positively affects social value in SMEs. 


\subsection{Innovation management and reputation}

We consider corporate reputation to be the result of a process that stems from the firm's behaviour towards its stakeholders as well as the business's capacity to meet their expectations, under the premise of transparent information (De Quevedo et al. 2005). Reputation explained on the resource-based theory (Barney 1991; Hall 1992) is a source of competitive advantage, since it meets the requirements of being a strategic resource and a dynamic capacity that endows the firm with value (Martínez and Olmedo 2010).

Although SMEs do not convey their image strategies with the same degree of effectiveness as large firms (Nedungadi 1990), reputation may be seen as a vital intangible resource for them, regardless of the size of the firm (Rindova et al. 2005). Over the last few years, reputation has become a key tool in the academic, business and professional spheres (López and Iglesias 2010). We find few references in the literature that examine the issue of reputation in SMEs, with very few empirical works having been carried out (Goldberg et al. 2003; Abimbola and Kocak 2007).

The study by Hormiga and García-Almeida (2016) examines how to create reputation through innovation strategies and prior knowledge and confirms how these two variables play a leading role in developing reputation in the early years of the firm's existence. As a result, we believe that innovation is a very important means of securing a reputation.

Sridhar and Mehta (2018) find a positive relation between service innovation and corporate reputation, and how these have an impact on customer purchase intention. They show empirically that corporate reputation acts as a mediating variable between service innovation and purchase intention. Burdon et al. (2017) evidence that organisations which are able to forge a sound reputation thanks to innovation appeal to other firms when it comes to establishing alliances, due to the competitive advantage obtained. Moreover, in addition to external image, innovation can lead to a significant improvement in the firm's competitive position in the market.

Chun (2006) confirms in his study that innovation is a factor that has a positive influence on business reputation. In this regard, he highlights the birth of a hybrid term; corporate social innovation or sustainable innovation. Following the same line, Halme and Korpeda (2014) posit a study which analyses the resources required by SMEs for responsible innovation, developing a model in which reputation is one of the most relevant factors for SMEs. Bae et al. (2014) also conducted a study along the same line, with the results showing that corporate reputation is deemed a key resource for SMEs to become innovative firms. The work by ValdezJuárez et al. (2018) shows that SMEs who engage in social and sustainable practices increase their level of innovation and enhance their image, reputation and financial profitability.

For these reasons, we posit the following hypothesis:

Hypothesis 2 Innovation management has a significant and positive influence on reputation in SMEs. 


\subsection{Reputation and creation of shared value}

Corporate reputation enables SMEs to achieve greater CSV in the dimensions of social value and business value. The empirical evidence has analysed the link between corporate reputation and performance, both in financial as well as social terms, and suggests that a positive reputation translates to both economic and noneconomic benefits (Fernández-Sánchez and Luna-Sotorrio 2007; Flatt and Kowalczyk 2011), with non-economic benefits being understood as those which we refer to as social. Studies such as those carried out by Raithel and Schwaiger (2015) conclude that reputation can even have a more positive impact on non-financial or social aspects.

We find literature that links reputation to the indicators which we use in the model to measure business value and social value; the two dimensions of CSV. With regard to business value, a positive reputation is associated to achieving a greater capacity to create shareholder value (Miralles-Marcelo et. al. 2014), with the possibility of obtaining better ratings from analysts (Cordeiro and Sambharya 1997), with securing positive financial results (Nanda et al. 1996; Roberts and Dowling 1997, 2002; De la Fuente et al. 2003; Saeidi et al. 2015), and even with improved financial performance when compared to previous years (Maruf 2013), with greater profitability (Eberl and Schwaiger 2005), and risk reduction (Helm 2007). Indeed, most empirical studies addressing the value of reputation have analysed the positive financial side and have found that companies which enjoy a better reputation compared to the average (Black et al. 2000; Deephouse 2000) are able to enhance their capacity, outperform their competitors, boost their revenue and cut costs (Schnietz and Epstein 2005).

As regards social value, reputation has a positive effect on perceived quality (McGuire et al. 1990), a better relation with current clients and the ability to attract new clients (Ali et al. 2020), on increased levels of confidence amongst other stakeholders (Flavian et al. 2005) and on a better market position (Hall 1992). For Arslanagic-Kalajdzic and Zabkar (2017), the greater the business reputation, the greater the perceived value amongst clients, which therefore leads to greater social value. This link is even more intense when what the firm offers is intangible, given that clients have greater difficulty evaluating quality objectively, such that their perception is determined by the firm's reputation. In our model, in social value we include similar indicators to those described, such as customer satisfaction and product quality. As a result, and in line with the many studies reviewed in the literature, we assume there is a relation between the two variables. Some studies include the two dimensions of CSV. Cabral (2012) shows how a positive reputation leads to enhanced business performance (business value) and increased customer satisfaction (social value).

Our empirical study focuses on Spain. When reviewing other applied studies in terms of the country of origin, North-American firms evidence a positive relation between corporate reputation and CSV (Cordeiro and Shmabhraya 1997; Black et al. 2000; Riahi-Belkaoui 2004; Jiao 2010). In other countries, such as Germany (Dunbar and Schwalbach 2000), Denmark (Rose and Thomsen 2004) or Australia (Inglis et al. 2006), analysis fails to provide any proof of a significant impact. This means that the country factor may prove to be important when drawing conclusions. 
Due to their proximity to their stakeholder groups, SMEs have a specific capacity to positively manage their relations and enhance their competitiveness, optimising their economic, social and environmental performance, which leads us to posit the following research hypotheses:

Hypothesis 3a The greater a company's reputation, the stronger its business value.

Hypothesis 3b The greater a company's reputation, the stronger its social value.

\subsection{Social value and business value}

A distinction is often drawn between the conventional businessperson and the social businessperson, with the idea being that the former focuses on the creation of financial value and the latter on the creation of social value (Auerswald 2009). We propose a model in which we include the two dimensions jointly, since we consider that managers of SMEs should pursue the two values equally.

In the literature, we find studies evidencing firms' capacity to create social and business value, with the two emerging as inseparable from each other (Porter and Kramer 2011; Dembek et al. 2016). When businesses make a commitment to social development in their immediate (local) environment, they are not only improving the level of social well-being but are also contributing to the area's competitiveness. Firms not only create social value through direct benefits for society but also participate in social activities that have an impact in the medium and long term. They enhance transparency and responsibility, increase consumers' capacity to choose, and introduce technological and organisational innovations (Rubio-Andrés et al. 2020).

As the origin of the concepts of social value and business value, we find the study by Van Beurden and Gössling (2008). These authors conducted a thorough review of the literature up to 2007, analysing the link between corporate social performance (CSP) and corporate financial performance (CFP), and concluded that there is a positive link. An ever-increasing number of studies are pointing to financial benefits that are the result of social performance (Berman et al 1999; Orlitzky and Benjamín 2001). For example, Auerwald (2009) highlights the transformative power of SMEs to create social value. Li et al. (2018) provides empirical evidence of a positive and significant relation between business value and social value in CSV. The results to emerge from their study agree with the notion that firms create shared value when they achieve business value and, that by meeting the needs of their environment, they convey social value. This is because firms gain the trust of the community in which they undertake their activity and secure fresh value generation (Tokoro 2015). Recently, Soufre and Gopalakrishna-Remani (2019) put forward the hypothesis that firms' social performance is positively linked to financial performance, although they do not confirm it empirically.

For these reasons, we consider that the social dimension affects the economic dimension in CSV, such that we establish the following hypothesis:

Hypothesis 4 Social value has a significant and positive influence on business value in SMEs. 


\subsection{The mediating role of reputation and social value in the model}

Some previous studies have taken an interest in the mediating role played by business reputation vis-à-vis the stakeholders involved, between an independent variable and financial performance, and have shown through an applied approach how there is a positive impact (Rindova et al 2005; Schnietz and Epstein 2005; Flatt and Kowalczyk 2011; Wang and Berens 2015). In our case, the independent variable we evaluate is innovation management.

Weng and Chen (2017) suggest that reputation stems from internal innovation and the management of intangible assets linked to employees, which in turn affects business value. In the same line, we find specific indicators of innovation management of human resources which we have considered within innovation management as those that generate a good reputation, with this latter variable being able to create business value and retain the principal stakeholders (Black et al. 2000).

Indeed, reputation protects firms against possible losses in value, due to the concern for the quality of products and services as well as workers' job security, which translates to receiving a better evaluation from the market (Schnietz and Epstein 2005), and which might prove to be a risk should the expectations created not be met and thereby have a negative impact on business value (Gatzert 2015).

All of these results show how business value in SMEs is not only linked directly to innovation management but is also mediated by variables involved in the relation, such as reputation and social value, the principal axis of this study.

For the mediating analysis of these hypotheses, we follow the steps described by Baron and Kenny (1986) through indirect effects. We therefore propose the following hypotheses:

Hypothesis 5a In the relation between innovation management and social value, reputation acts as a mediating variable.

Hypothesis $\mathbf{5 b}$ In the relation between innovation management and business value, social value acts as a mediating factor through SMEs' reputation.

The literature establishes a link between firms' social performance and financial performance, based previously on the value of business reputation (Schnietz and Epstein 2005). Research into the link between reputation and CSV suggests that the benefits of a good reputation are not only financial but that non-financial advantages also emerge (Flatt and Kowalczyk 2011) and which act as mediators. Taking into account these claims, we propose the following mediating hypothesis:

Hypothesis 5c Social value acts as a mediating variable in the relation between reputation and business value.

Below is a graphical representation of the empirical model with the hypotheses proposed (see Fig. 1). 


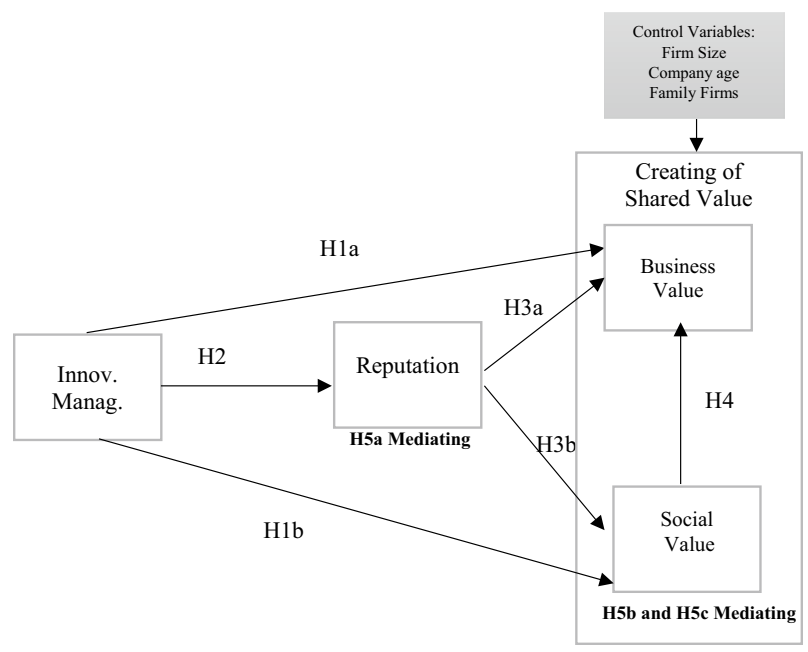

Fig. 1 Conceptual framework Source: Own

\section{Methods}

\subsection{Sample design and data collection}

SMEs operating in Spain randomly selected from the database of DIRCE 2018. The selection framework was the SABI database. Sampling was performed through stratification of the population. Stratification criterion were established in accordance with the aims of the study and the information available concerning the population structure. A total of 1136 completed surveys were returned and used for further analysis in this study. About sampling error, the final distribution obtained achieves a maximum error in the estimation of a proportion of $2.9 \%$ with a confidence level of $95 \%$.

The largest group of participating firms was from the services sector (37.9 percent), followed by industry (26.6 percent), retail (18.8 percent), and construction (16.6 percent). Besides, the majority of firms had a small size with fewer than 50 employees (50.7 percent), followed by Micro-SME with 6-9 employees (40.4 percent) and medium with 50-249 employees (8.9 percent).

In addition, Table 1 provides more extensive descriptive statistics for the total number of Spanish SMEs participating in the study.

\subsection{Measures}

The questionnaire was designed specifically for the present study by selecting indicators, variables and the links between them, following the relevant literature. For the measurement of the indicators, SME owner-managers were asked to indicate the level of agreement on 28 items using a 5-point Likert scale ( $1=$ "strongly disagree" and $5=$ "strongly agree"). 
Table 1 Sample of SMEs in Spain. Source: Own

\begin{tabular}{|c|c|c|}
\hline & Number & Percentage $(\%)$ \\
\hline \multicolumn{3}{|l|}{ Age (years) } \\
\hline $1-10$ & 95 & 8.4 \\
\hline $11-20$ & 323 & 28.4 \\
\hline $21-30$ & 365 & 32.1 \\
\hline$>30$ & 353 & 31 \\
\hline \multicolumn{3}{|l|}{ Sector } \\
\hline Industry & 302 & 26.6 \\
\hline Construction & 189 & 16.6 \\
\hline Retail & 214 & 18.8 \\
\hline Service & 431 & 37.9 \\
\hline \multicolumn{3}{|l|}{ Number of employees } \\
\hline 6-9 & 459 & 40.4 \\
\hline $10-50$ & 576 & 50.7 \\
\hline $51-249$ & 101 & 8.9 \\
\hline \multicolumn{3}{|l|}{ Average qualification } \\
\hline Secondary Education & 136 & 12.0 \\
\hline Sixth Form- Further Education & 361 & 31.8 \\
\hline University Education & 639 & 56.3 \\
\hline \multicolumn{3}{|l|}{ Family business } \\
\hline Yes & 785 & 30.9 \\
\hline No & 351 & 69.1 \\
\hline \multicolumn{3}{|l|}{ Gender } \\
\hline Male & 975 & 85.8 \\
\hline Female & 161 & 14.2 \\
\hline
\end{tabular}

Sampling error: $2.9 \%$. Confidence level $95 \%$

Churchill's (1979) approach to questionnaire development was used. Scales were combined from several other relevant empirical studies along with new items to make an initial list of 36 items distributed as follows: 16 that focused on measuring innovation management, 4 focused on measuring reputation, 9 focused on social value and, finally, 7 items focused on measuring business value.

\subsection{Variables}

The construct that forms the innovation variable is made up of indicators such as significant improvements in management, procurement and marketing, HRM innovation, digitisation of SMEs, new technologies (Battaglia et al. 2014; Burdon et al. 2015; Cegarra-Navarro et al. 2016; Lichtenthaler 2017; Sridhar and Mehta 2018).

Reputation is a construct that is made up of the following manifest variables: positive customer experience, positive image and reputation, transparency (Barney 1986; De Hall 1992; De Quevedo et al. 2005; Martínez and Olmedo 2010).

Social value lists as dimensions of social value creation quality of the products, efficiency of the process, customer satisfaction, rapid anticipation of environmental changes, motivation of workers, work absenteeism, reducing the consumption of 
energy and other resources, establishing recycling measures (Wu 2006; Van Beurden and Gössling 2008; Auerswald 2009; Thompson and MacMillan 2010; Florin and Schmidt 2011; Porter and Kramer 2011; Li et al. 2018).

Business value is the main endogenous variable where all the latent variables of the model converge; the indicators that measure this construct are: Business growth, Profitability, reduction of business costs, improved sales expectations, lower financial costs (Clark 2000; Bocquet et al. 2013; Rasoulzadeh et al. 2013; Saeidi et al 2015; Sridhar and Mehta 2018; Pekovic and Vogt 2021).

\subsubsection{Control variables}

We control for a series of variables that may affect a firm's CSV decisión. Specifically, as control variables, we propose company age, firm size and family firms. Empirical literature identified these variables as factors that may affect firms' financial performance (Wang and Berens 2015) and social value.

Company Age is the number of years the organisation has been running. We distinguish between new-born firm and older firm, with new-born firms being those less than ten years old. A dummy variable was created for company age and takes the value 0 if the company is a newborn firm and 1 if it is an older firm. The reason for the inclusion of company age is that it can affect financial and social value (Ali et al. 2020).

Firm size was modeled as a single indicator to account for the role of different firm sizes in explaining CSV. This variable is calculated as the average number of employees of the company in 2018. We encoded 0 when the company is a small enterprise (6-49 employees) and 1 when the company is a medium enterprise (50-249 employees).

Finally, we also control family firms variable. Previous studies have used family firms to test whether they affect social activities (Zhong and $\mathrm{Wu} 2021$ ), a concept that is aligned with social value. Family firms is a dummy variable and takes the value of 1 if two or more family members have ownership or management and 0 otherwise.

\subsection{Data analysis}

As suggested by Hair et al. (2011), due to the complexity of the model (many constructs and many variables) and the exploratory nature of our study, which focuses on predicting the endogenous variables, we apply Partial Least Squares-Structural Equation Modelling (PLS-SEM) to evaluate the research model. Our model is reflective because causality occurs from the construct to its measures, which is why we consider the indicators to be a representative sample of all the possible items available within the corresponding construct (Hair et al. 2011). For this reason, the indicators associated to the construct are closely correlated with one another. As long as the items have sufficient reliability, they are interchangeable and so could be left out individually without altering the sign of the construct. We use SmartPLS (Ringle et al. 2015) to 
analyse the data in two steps, including the measurement models and structural model. When evaluating the reflective measurement model, there is a need to consider: the internal consistency, the convergent validity, and the discriminant validity. In order to evaluate the structural model, a bootstrap procedure with 5000 sub-samples was used, and 1136 bootstrap cases, without there being any change in sign. We calculated: collinearity in the structural model (VIF), coefficient of determination (R2), predictive relevance (Q2), and sizes of the f2 effects. Structural equation modelling (SEM) is more suitable than regression analysis in this type of research (Galbreath and Shum 2012; Saeidi et al. 2015). According to Ramli et al. (2019), the discussion so far has stated that mediation issues in scientific research have become more complex, particularly when three, four or more variables are involved, since these variables may have indirect effects (mediation) on some relations.

\subsection{Results}

In order to analyse the relationships between the different constructs and their indicators, the latent model perspective is adopted, in which the latent variable is understood to be the cause of the indicators. This study therefore refers to reflective indicators for first-order constructs or dimensions. Four constructs in the model are operationalized as first-order reflective constructs (i.e. innovation management, reputation, social value and business value). This study begins by assessing the individual item reliability for the measurement model. The indicators exceed the accepted threshold of 0.7 for each factor loading (Carmines and Zeller 1979).

Results of the analysis confirmed the reliability and convergent validity of the measurement model (Table 2). In terms of reliability, all constructs had a composite reliability higher than the threshold of 0.7 .

The Cronbach's Alpha obtained in the present research were also considered satisfactory because the values are over 0.70 (Hair et al. 2006) (between 0.876 and 0.843 ), which confirms the constructs' high reliability. Composite reliability is a more recommendable criterion and would reach an appropriate value (0.899) (Fornell and Larcker 1981).

Moreover, convergent validity was established as the average variance extracted (AVE) for all constructs was higher than 0.5 , and all indicators were significant with outer loadings of more than 0.5 , with the exception of the innovation management

Table 2 Descriptive statistics and correlation matrix. Source: Own

\begin{tabular}{lllllllll}
\hline Indicators & SD & CA & CR & AVE & 1 & 2 & 3 & 4 \\
\hline Business value & 0.718 & $\mathbf{0 . 8 4 7}$ & $\mathbf{0 . 9 2 9}$ & $\mathbf{0 . 8 6 7}$ & $\mathbf{0 . 9 3 1}$ & & & \\
Innovation management & & $\mathbf{0 . 8 7 6}$ & $\mathbf{0 . 8 9 9}$ & 0.428 & 0.435 & $\mathbf{0 . 6 5 4}$ & & \\
Reputation & 0.885 & $\mathbf{0 . 8 4 3}$ & $\mathbf{0 . 9 2 7}$ & $\mathbf{0 . 8 6 5}$ & 0.385 & 0.466 & $\mathbf{0 . 9 3 0}$ & \\
Social value & 0.820 & $\mathbf{0 . 8 7 1}$ & $\mathbf{0 . 9 0 3}$ & $\mathbf{0 . 6 0 9}$ & 0.687 & 0.538 & 0.426 & $\mathbf{0 . 7 8 0}$ \\
\hline
\end{tabular}

$\mathrm{SD}=$ Standard Deviation $\mathrm{CA}=$ Cronbach's Alpha; $\mathrm{CR}=$ Composite Reliability; AVE = Average Variance Extract. The bold numbers on the diagonal are the square root of the Average Variance Extracted. Offdiagonal elements are correlations among constructs 
construct, which achieves a very close AVE (0.428), although its cross-loadings are within the recommended values and between (0.4-0.7). The comparison between the square root of the AVE (i.e., the diagonals of Table 2) and the correlations between the combinations (i.e., the bottom triangle of the matrix in Table 3) determines the validity of the discrimination index. On average, each relationship has a stronger relationship with its measures than others argued (Fornell and Larcker 1981). Table 2 shows the means and standard deviations of the construct's correlation matrix.

The Cross-loading matrix show that the load of an indicator in its corresponding latent variable is greater than its loads crossed with the rest of the latent variables. We observe the loads between the indicators of all the latent variables and see how an indicator's load in its associated construct is much greater than its load in the other constructs (Table 3 ).

We then verified the discriminant validity of measurement model through the Heterotrait-Monotrait (HTMT) approach (Table 4), as the HTMT ratio for all constructs was below the threshold of 0.90 recommended by Gold et al. (2001).

Table 3 Cross-loading matrix. Source: Own

\begin{tabular}{|c|c|c|c|c|}
\hline Indicators & Business value & $\begin{array}{l}\text { Innovation manage- } \\
\text { ment }\end{array}$ & Reputation & Social value \\
\hline IN_1 & 0.247 & 0.724 & 0.270 & 0.343 \\
\hline IN_3 & 0.291 & 0.566 & 0.305 & 0.315 \\
\hline IN_4 & 0.300 & 0.549 & 0.305 & 0.292 \\
\hline IN_7 & 0.296 & 0.521 & 0.281 & 0.262 \\
\hline IN_8 & 0.300 & 0.771 & 0.296 & 0.388 \\
\hline IN_10 & 0.302 & 0.676 & 0.306 & 0.377 \\
\hline IN_11 & 0.305 & 0.728 & 0.333 & 0.395 \\
\hline IN_12 & 0.282 & 0.709 & 0.294 & 0.369 \\
\hline IN_13 & 0.375 & 0.610 & 0.415 & 0.443 \\
\hline IN_14 & 0.231 & 0.656 & 0.282 & 0.330 \\
\hline IN_15 & 0.208 & 0.675 & 0.300 & 0.352 \\
\hline IN_16 & 0.194 & 0.614 & 0.176 & 0.258 \\
\hline BV_1 & 0.928 & 0.391 & 0.340 & 0.628 \\
\hline BV_2 & 0.934 & 0.418 & 0.376 & 0.651 \\
\hline SV_2 & 0.430 & 0.370 & 0.304 & 0.726 \\
\hline SV_3 & 0.563 & 0.396 & 0.293 & 0.779 \\
\hline SV_4 & 0.523 & 0.401 & 0.357 & 0.832 \\
\hline SV_5 & 0.586 & 0.447 & 0.346 & 0.812 \\
\hline SV_6 & 0.623 & 0.520 & 0.365 & 0.811 \\
\hline $\mathrm{SV}_{-} 7$ & 0.455 & 0.354 & 0.324 & 0.714 \\
\hline RP_3 & 0.374 & 0.433 & 0.932 & 0.399 \\
\hline RP_4 & 0.341 & 0.434 & 0.928 & 0.392 \\
\hline
\end{tabular}

Bold values indicate highest load value of each indicator 
Table 4 Evaluation of discriminant validity using heterotrait-monotrait ratio. Source: Own

Business value Innovation man- Reputation $\quad$ Social value
agement

\begin{tabular}{llll} 
Business value & & & \\
Innovation management & 0.495 & & \\
Reputation & 0.455 & 0.531 & \\
Social value & 0.791 & 0.598 & 0.496 \\
\hline
\end{tabular}

We examined the residual matrix of correlations and found there were no significant residual values that would indicate a substantial prediction error for the indicators or manifest variables that make up each of the constructs in the model.

After confirming the reliability and validity of the measurement model, we performed collinearity diagnostics (structural model) and found that the highest VIF for predictor variables was 1.557, well below the threshold of 3 (Hair et al. 2019). Hence, collinearity was not an issue in the structural model, so it was not necessary to eliminate constructs or create higher order constructs.

Table 5 and Fig. 2 shows the results for the beta $(\beta)$ coefficient, degree of significance, and importance of the value distribution using Student's t-test. To test the hypotheses a bootstrapping procedure with 5000 subsamples was used, as recommended by Chin (1998).

All of the proposed hypotheses are accepted, with $p$ values being below 0.05 , and zero is not included in the confidence intervals. Looking in greater detail, we see how $\mathrm{H} 1 \mathrm{a}$, which evaluates the direct relation between innovation management and business value, is significant but with a $p$-value $=0.037(\beta=0.060$, $\mathrm{T}=2.088$ ). This is due to the existence of mediating variables that will be explained later in the mediation analysis. We now comment on the rest of the hypotheses in accordance with the constructs posited.

Hypothesis 2 is supported. Innovation management has a significant and positive influence on reputation in SMEs $(\beta=0.466, \mathrm{~T}=19.333, \mathrm{p}=0.000)$.

The hypotheses concerning $\mathrm{H} 3 \mathrm{a}$ and $\mathrm{H} 4$ of the constructs have a direct relationship with business value, and all of them are supported, reputation $(\beta=0.095$, $\mathrm{T}=2.955, p=0.003)$ and social value $(\beta=0.0614, \mathrm{~T}=23.006, p=0.000)$ to business value.

Hypothesis 4 describes the direct causality between social value and business value. The results showed a significant positive relationship with a significant impact of $61.4 \%$, as shown in Table 5 .

The hypotheses concerning $\mathrm{H} 1 \mathrm{~b}$ and $\mathrm{H} 3 \mathrm{~b}$ of the constructs have a direct relationship with social value and are all supported, thus indicating the importance of innovation management $(\beta=0.433, \mathrm{~T}=15.169, p=0.000$ and reputation $(\beta=0.224, \mathrm{~T}=7.013, \mathrm{p}=0.000)$. H1b, which depicts direct causality between innovation management and social value, showed a significant positive relationship with an impact of $43.3 \%$ as shown in Table 5.

As the three control variables (company age, firm size and family firms) are categorical, we conducted a multigroup analysis to assess possible differences. 


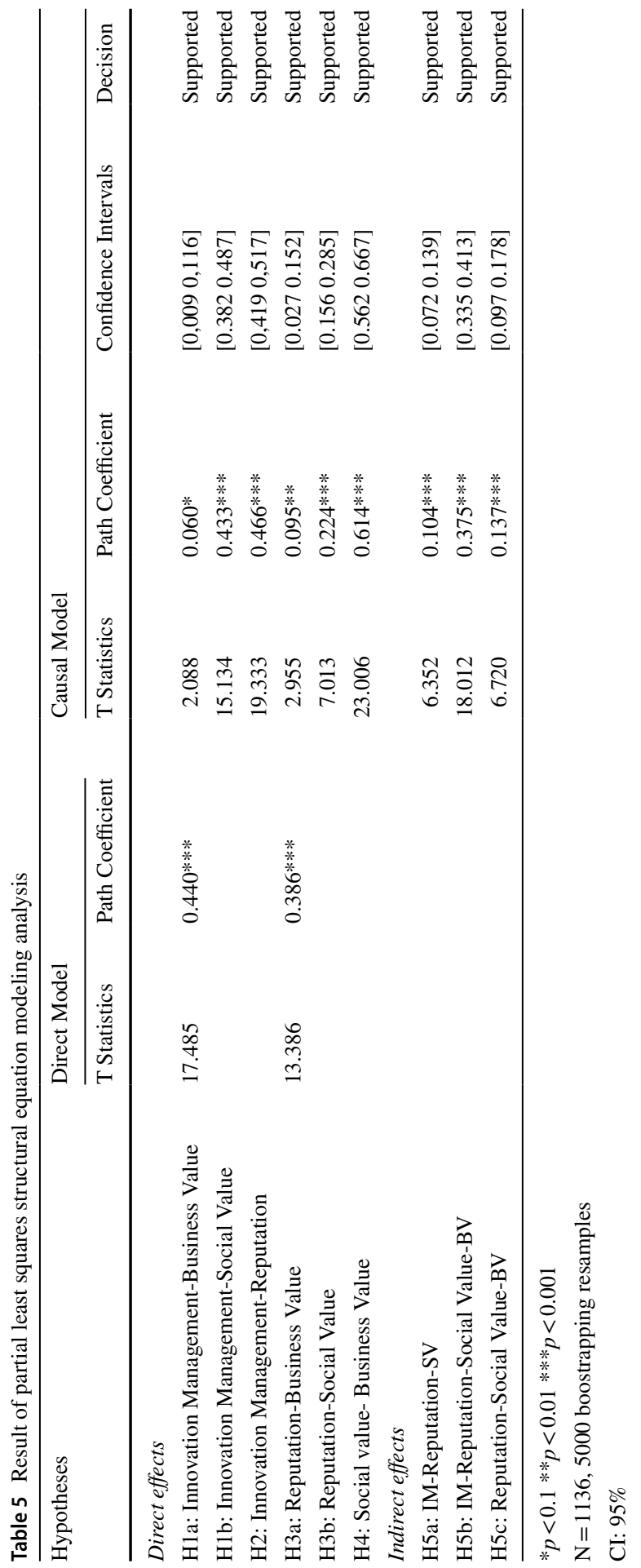




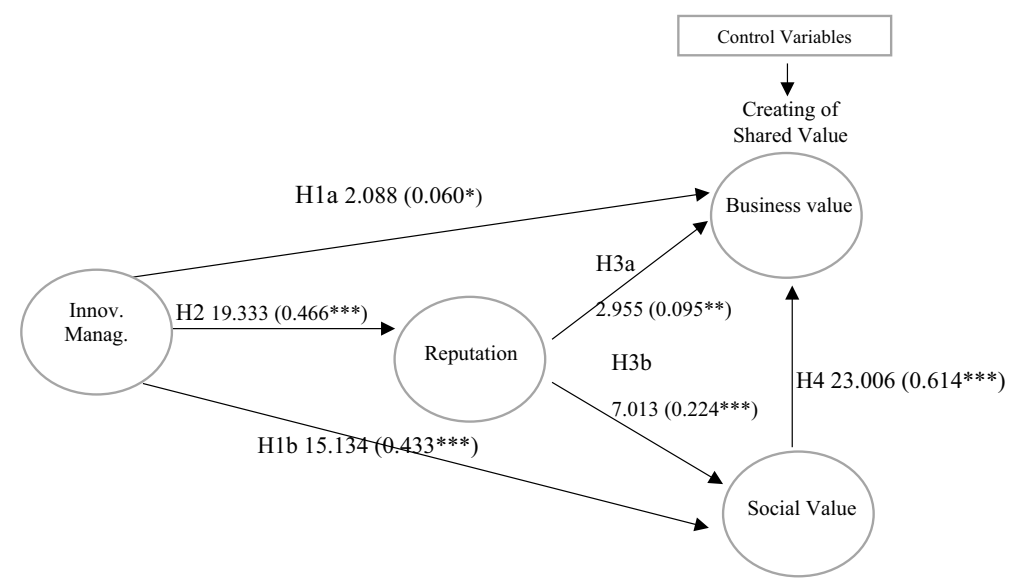

Fig. 2 Results measurement model

This approach offers a more comprehensive view of what influence the mediating variable has on the results obtained by examining its impact on all the model's relations (Hair et al. 2011). According to the Partial Least Squares Multi-Group Analysis (PLS-MGA) (Henseler et al. 2009) approach, in the cases highlighted, the differences are not significant in control variables $(p>0.05)$, which is consistent with other studies that confirm the lack of influence which some of our control variables, such as reputation and business value (Lee et al. 2009; Galbreath and Shum 2012; Saeidi et al. 2015) are seen to display.

\subsection{Analysis of mediation}

We used the bootstrapping technique to analyse the mediating hypotheses (H5a, H5b and H5c). We follow Baron and Kenny (1986) in their explanation concerning the need to create two models to study the relevance of the mediating variable. The initial model analyses the impact without mediation. In our case, we have two independent initial models. The first studies the direct link between innovation management and business value and finds a highly significant relation between the two variables; $p=0.000(\beta=0.440 \mathrm{~T}=17.485)$. The second initial model reflects the direct relation between reputation and business value and is equally significant $p=0.000(\beta=0.386 \mathrm{~T}=13.386)$.

We then create the final causal model, including all the mediating variables. We see how the direct relations studied in the initial models continue to prove significant ( $p=0.037$ and $p=0.003$, respectively), albeit with less importance, particularly in the case of innovation management on business value. We thus confirm the existence of partial mediation in the model: in other words, there is a direct relation between the independent variable and the dependent variables, and at the same time a significant link between the mediating variable and the dependent variable. We therefore confirm hypotheses $5 \mathrm{a}, 5 \mathrm{~b}$ and $5 \mathrm{c}$. 
In order to gauge the importance of the impact of the mediating variables, we test their indirect effect. Table 5 shows the numerical values. The mediation of reputation between innovation management and social value is partial (H5a), with a low indirect effect (0.104), but a high and significant direct effect (0.433). As regards the link between innovation management and business value, we highlight the mediating effect of reputation and social value, with a high total indirect effect $(0.375)$ as opposed to a low direct effect (0.060), thereby confirming the mediating hypothesis put forward (H5b). In this multiple mediation relation, there are three joint effects (Hair et al. 2011); social value (0.266), reputation (0.044), and the mediation of social value through reputation (0.064). We therefore confirm the hypothesis posited and show that in the relation between innovation management and business value, social value acts as a mediating factor through SMEs' reputation. As regards the relation between reputation and business value, we also confirm the mediating effect of social value, H5c, although we do find the indirect effect to be less significant (0.137) when compared to the previous mediation.

\subsection{Predictive relevance of the model}

Through the following indicators, we evaluate the model's predictive relevance. The coefficient of determination $\left(\mathrm{R}^{2}\right)$ of the main endogenous variables (business value and social value) reaches high values, 0.485 and 0.328 respectively. If we consider the effect size $f^{2}$, we can confirm a major effect of social value on business value (0.492) and a medium effect of innovation management on reputation (0.278) and social value (0.219). In the case of reputation on social value, the effect of size is significant, albeit small (0.058). Finally, the blindfolding-based cross-validated redundancy values $\left(\mathrm{Q}^{2}\right)$ for all the endogenous variables were above zero, confirming the model's predictive relevance.

\section{Discussions}

\subsection{Theorical implications}

Our paper, which focuses on the concept of CSV, is grounded on the proposal of Porter and Kramer (2011) concerning the creation of business value, such that firms also generate value for society by meeting the latter's need and challenges. In this way, a firm shares the value created when, in addition to generating profit, it also creates social value (Salas Fumás 2011). Indeed, CSV is a new concept which should be the focus of attention for SMEs who hope to succeed in the market.

One point worth highlighting is that social value has been more widely studied in the literature addressing social entrepreneurship and non-profit firms (Auerwald 2009; Kroeger and Weber 2014; Sinkovics et al. 2014). Nevertheless, in our research we consider that social value is possible regardless of the firm's social aim, and "for profit" SMEs should not renounce the generation of social value for 
the benefits of achieving it, such as improving their own financial performance. In this regard, Acs et al. (2013) suggest that all business initiatives pursue a twofold objective; to create social value and economic value, whilst being aware that social value can be created without the firm specifically setting out to achieve it. In the model presented, social value is a key dimension for SMEs, given its direct and mediating effect on business value.

It is currently acknowledged that the specific characteristics of SMEs mean that the latter need to be approached differently vis-à-vis large firms (MuñozPascual et al. 2019; Beaver and Jennings, 2000) when it comes to aspects such as decision making, management styles, organisational structures and business cultures, although what both large and small firms do have in common is that management cannot be separated from stakeholder motivation (Beaver 2003). Organisations need to perform well in order to continue, and this is even more so the case for SMEs, if they are to survive. This was borne out in the study conducted by Jennings and Beaver (1995), who showed that SMEs which had been more active in making improvements in products, processes and organisational change were the most successful in terms of survival. In their study, Venâncio et al. (2020) recommend training for entrepreneurs so as to turn them into "quality entrepreneurs" and so ensure the firm's future performance. All these differences justify our study's focus on SMEs for their own causality.

Our study helps to bridge the research gap in the emerging field of CSV in a number of ways; highlighting its importance in SMES (key companies in the Spanish and European business fabric), such as through the greater proximity to stakeholders when compared to large companies or by contributing fiscally through the payment of local taxes in the region in which they operate (JofreMonseny and Solé-Ollé 2010, 2012; Jofre-Monseny 2013). We also further current understanding concerning how innovation management in SMEs achieves CSV, valuing the impact of positive reputation on social and business value, and underscoring the role played by social value throughout the whole process. We follow the recommendation of Soufre and Gopalakrishna-Remani (2019) vis-àvis the need to promote studies that empirically analyse influential variables in CSV. For our case study, we analyzed previous studies that examined the relationships between the variables listed above, as well as the metrics used to measure them, in order to clarify the impact of innovation and reputation management on CSV. As a result, we developed our own model, verifying direct, indirect, and mediating relationships.

\subsection{Practical and managerial implications}

Current research continues to address the issue concerning the degree to which innovation management in SMEs helps to create shared value, and studies reflect the critical need to understand the role and impact of reputation and social value. Clauss et al. (2020) carried out a study using data from SMEs and provided empirical evidence regarding the importance of an innovation management approach based on what they term Business Model Reconfiguration (BMR). Our empirical study 
into Spanish SMEs also reveals significant conclusions in this regard, bringing to light how innovation management enhances a firm's reputation and image, exerting a two-fold impact on the creation of social value and economic value.

In relation to the proposed topic, we have set four research questions described in the introduction. Each question corresponds to a study objective and is specified in the corresponding hypotheses.

We point to the following specific findings:

In order to meet our first research objective, we include in our model the firm's capacity to innovate, considering innovation in products, processes, the organisation and human resources (Bouquet et al. 2013) and their impact on CSV (Lichtenthaler 2017). Based on this objective, we assess the importance of SMEs' capacity for innovation as a prior step towards the creation of shared value, and we formulate two hypotheses, $\mathrm{H} 1 \mathrm{a}$ and $\mathrm{H} 1 \mathrm{~b}$, related to the impact of innovation management on business value and social value, respectively. In the empirical research, we show that process innovation, together with organisational innovation, management innovation and human resources innovation, create social and business value. As explained in the literature, we confirm the importance of implementing innovation management that merges the various types of innovation rather than merely optimising each kind of innovation separately (O'Regan and Ghobadian 2004; Lau and Tovstiga 2015). Designing new products and/or services stemming from innovation management offers new market opportunities that are beneficial for both the firm as well as for society, thereby generating CSV (Corazza et al. 2017; Obsuwan et al. (2021). found factors that enhanced team performance, such as creativity and satisfaction, highlighting the need to improve these two factors through human resource innovation. SMEs must first implement innovation management practices before they can create value.

We recommend SME managers to consider the opportunities afforded by innovation in the business model, based on product and/or process innovation, improved quality, customer satisfaction (Amit and Zott 2012), and better performance (Blakely and Aparicio 1990; Nicholls 2008; Swanson and Di Zhang 2010; Bagnoli and Megali 2011; Battaglia et al. 2014). Innovation management enables managers to resolve the apparent disconnect between the costs and benefits of innovation, establishing a different business model that involves stakeholders in new systems of value creation. Despite the difficulties highlighted by Málovics et al (2008), our findings indicate that achieving shared value creation starts with innovative leadership to achieve social and economic goals.

The second objective marked out, and which concerns the impact of innovation management on the firm's reputation, is extremely interesting because además reputation plays a mediating role in the model. In relation to this, we define hypothesis 2 in order to gauge the impact of innovation management on SMEs' reputation. When reviewing the literature, several authors report a positive relation between innovation and corporate reputation (Chun 2006; Hormiga and García-Almeida 2016; Sridhar and Mehta 2018), such that empirical support for this hypothesis has been shown. In this way, innovation has a positive impact on reputation in SMEs.

As a third objective, we value the direct effects of reputation and social value on the business value variable. This is detailed in part in hypotheses $3 \mathrm{a}$ and $3 \mathrm{~b}$, 
which deal with how the latent variable of reputation has a positive and significant impact on business value and social value, respectively. Hypothesis 4 is designed to study the direct relation between social value and business value (CSV). Confirming these hypotheses once again implies endorsing the link which, according to the literature, exists between reputation and CSV (McGuire et al 1990; Nanda et al 1996; Cordeiro and Sambharya 1997; Roberts and Dowling 1997, 2002; De la Fuente et al. 2003; Fernández-Sánchez and Luna-Sotorrio 2007; Miralles-Marcelo et al. 2014; Ali et al. 2020). Our research provides empirical evidence that a positive reputation leads to more satisfied clients and employees and gives rise to business growth and more sustainable profitability.

The fourth objective focuses on the mediating effects set out in hypotheses $\mathrm{H} 5 \mathrm{a}, \mathrm{H} 5 \mathrm{~b}$ and $\mathrm{H} 5 \mathrm{c}$ in the model. Results show that reputation and social value promote the link between innovation management and business value. By analysing the indirect effects, we see there is multiple mediation (Baron and Kenny 1986). We show that in the relation between innovation management and business value, social value acts as a mediating factor through SMEs' reputation, with said mediating effect proving to be highly significant. In this regard, we find specific indicators in innovation management that are responsible for creating a good reputation, with this being the variable that can create business value (Black et al. 2000). The literature supports our finding, and research into the relation between reputation and CSV suggests that a good reputation leads to both financial as well as non-financial advantages (Flatt and Kowalczyk 2011).

In this regard, we recommend SME managers not only focus on developing innovation management but also on social value and reputation, since the mediating effect of the two variables significantly drives the direct effect of innovation management on business value. SME owner-managers should be concerned about the consequences of having a good reputation.

As a result, we show that if SMEs take an interest in innovation management, then they can enhance their reputation and will be able to create shared value in its two dimensions; social and business value. Innovation management enables corporate image to be improved, which helps to boost SMEs' reputation, whilst at the same time promoting the creation of business value within shared value. Moreover, social value is the dimension which emerges prior to the creation of business value. As a result, SMEs which can create better quality products for their clients, more efficient processes and more motivated staff (manifest variables of social value) will obtain greater profitability and sustainable growth in the markets.

\section{Limitations and future research}

We also need to recognise that it is not possible to solve all of society's problems by adopting a shared value approach, as explained by Porter and Kramer (2011). Although SMEs have the responsibility to engage in social commitment, from the standpoint of shared value creation it is not possible to deal with each and 
every key problem (Crane et al. 2014), although many of them can be successfully addressed.

A further point is that our empirical study has been carried out in Spain. Yet, given the importance of SMEs internationally, it would be interesting to conduct the analysis at a European or Latin-American scale.

Our method involved the use of surveys amongst SME managers, which is a common approach in social research (López-Pérez et al. 2017; Nejati et al. 2017). Nevertheless, we recognise that certain concepts may differ with regard to stakeholders, since a good reputation amongst investors may not necessarily mean there is a good reputation amongst workers (Ali et al. 2020; Gatzert 2015). Whenever possible, social value should be measured through sustainability reports, although SMEs do not tend to formally communicate their social performance (Baumann-Pauly et al. 2013) due to the lack of financial means.

As a future line of research, we propose an alternative model in which reputation is presented as an endogenous final variable, such that other variables like CSV have an impact thereon. One stream of research finds empirical evidence of two-way relations between business value and reputation (Fombrun and Shanley 1990; Lange et al. 2011), where past performance leads to a good future reputation (Rose and Thomsen 2004), a complex circular relation or "vicious circle" (Eberl and Schwaiger 2005; Gatzert 2015) with a "virtuous" orientation. We believe that it would be very interesting to create a new model that focused on exploring these relations.

Brand et al. (2019) reflect on which agility enablers accelerate innovation of products, services, and business models, and thereby foster business performance and growth. Rhaiem and Amara (2021) consider that organisational learning is another factor to be included in innovative processes. We believe this to be an attractive line of future research; in other words, addressing those agility factors and organisational learning that enhance innovation in SMEs.

Seeking fresh insights into social value due to the latter's importance in SMEs is another possible line of research, and one which is even more interesting since it offers part of the solution required to overcome the current economic crisis caused by the pandemic. It should be taken into account that the distinctive features involved in the size of SMEs lead to the forging of local ties and stability for their employees, which makes CSV even more appealing; hence the commitment to social value and its subsequent link to business value. The concept of social value has recently been addressed in the literature through other typologies (Dacin et al. 2010) such as the creation of cultural value, which can offer similar advantages to the inclusion of shared value (Wagner 2010; Muethel 2013; Sharma 2014; Khan 2015). These concepts might also be addressed in future studies.

\section{Conclusion}

SMEs that focus exclusively on short-term financial results miss the most important stakeholder needs that determine long-term success. To avoid this situation, a CSV-focused business vision would lead to sustainable SME growth. To identify 
initiatives to generate shared value, innovative management is fundamental to making strategic decisions. First, our study shows that to achieve CSV in its two dimensions (social and business), SMEs need innovative management that combines process, organizational, and managerial innovation. Furthermore, reputation plays a significant role in the process, since it represents innovative leadership, which encourages CSV, and therefore has a significant mediating effect. Finally, social value is the dimension that emerges social value is the dimension that emerges before business value.

Funding Open Access funding provided thanks to the CRUE-CSIC agreement with Springer Nature. The research is funded by UCM-Cofares Research Chair, INBOTS project H2020, Ministry of Economy and Competitiveness, Grant No. ECO2017-84209-P and ISDI.

\section{Declarations}

Conflict of interest The authors declare that they have no conflict of interest.

Open Access This article is licensed under a Creative Commons Attribution 4.0 International License, which permits use, sharing, adaptation, distribution and reproduction in any medium or format, as long as you give appropriate credit to the original author(s) and the source, provide a link to the Creative Commons licence, and indicate if changes were made. The images or other third party material in this article are included in the article's Creative Commons licence, unless indicated otherwise in a credit line to the material. If material is not included in the article's Creative Commons licence and your intended use is not permitted by statutory regulation or exceeds the permitted use, you will need to obtain permission directly from the copyright holder. To view a copy of this licence, visit http://creativecommons.org/licen ses/by/4.0/.

\section{References}

Abimbola T, Kocak A (2007) Brand, organization identity and reputation: SMEs as expressive organizations: a resources-based perspective. Qualitative Market Research 10(4):416-430

Acs ZJ, Boardman MC, McNeely CL (2013) The social value of productive entrepreneurship. Small Bus Econ 40(3):785-796

Ali HY, Danish RQ, Asrar-ul-Haq M (2020) How corporate social responsibility boosts firm financial performance: the mediating role of corporate image and customer satisfaction. Corp Soc Responsib Environ Manag 27(1):166-177

Amit R, Zott C (2012) Creating value through business model innovation. MIT Sloan Manag Rev 53(3):41-49

Arslanagic-Kalajdzic M, Zabkar V (2017) Hold me responsible: The role of corporate social responsibility and corporate reputation for client-perceived value. Corpor Commun Int J 22(2):209-219

Auerswald P (2009) Creating social value. Stanf Soc Innov Rev 7(2):50-55

Bae H, Rhee J, Kim C (2014) The effects of SME's corporate slack on innovation: moderating effect of corporate reputation. Asia Pacific J Small Bus 36(2):23-49

Bagnoli L, Megali C (2011) Measuring performance in social enterprises. Nonprofit Volunt Sect Q 40(1):149-165

Barney JB (1986) Organizational culture: can it be a source of sustained competitive advantage?. Acad Manage Rev 11(3):656-665. https://doi.org/10.5465/amr.1986.4306261

Barney J (1991) Firm resources and sustained competitive advantage. J Manag 17(1):99-120

Baron RM, Kenny DA (1986) The moderator-mediator variable distinction in social psychological research: conceptual, strategic, and statistical considerations. J Pers Soc Psychol 51(6):1173 
Battaglia M, Testa F, Bianchi L, Iraldo F, Frey M (2014) Corporate social responsibility and competitiveness within SMEs of the fashion industry: Evidence from Italy and France. Sustainability 6(2):872-893

Baumann-Pauly D, Wickert C, Spence LJ, Scherer AG (2013) Organizing corporate social responsibility in small and large firms: size matters. J Bus Ethics 115(4):693-705

Beaver G (2003) Management and the small firm. Strategic Chang 12(2):63

Beaver G, Jennings P (2000) Editorial overview: Small business, entrepreneurship, and enterprise development. Strategic Chang 9(7):397

Becerra-Vicario R, Leon-Gomez A, Gutiérrez-Ruiz AM, Fernandez-Gamez MA (2020) Sustainable development through corporate social responsibility, corporate philanthropy and creating shared value. Technium Soc Sci J 10:291

Berman SL, Wicks AC, Kotha S, Jones TM (1999) Does stakeholder orientation matter? The relationship between stakeholder management models and firm financial performance. Acad Manag $\mathrm{J}$ 42(5):488-506

Black EL, Carnes TA, Richardson VJ (2000) The market valuation of corporate reputation. Corp Reput Rev 3(1):31-42

Blakely EJ, Aparicio A (1990) Balancing social and economic objectives: the case of California's community development corporations. J Commun Develop Soc 21(1):115-128

Bocquet R, Le Bas C, Mothe C, Poussing N (2013) Are firms with different CSR profiles equally innovative? Empirical analysis with survey data. Eur Manag J 31(6):642-654

Börjesson S, Löfsten H (2012) Capabilities for innovation in small firms-a study of 131 high-tech firms and their relation to performance. Int J Bus Innov Res 6(2):149-176

Bouncken RB, Görmar L (2021) Entrepreneurial orientation in coworking-spaces for corporate entrepreneurship and venturing. Multidiscip Bus Rev 14(1):84-94

Bouncken RB, Reuschl AJ (2018) Coworking-spaces: how a phenomenon of the sharing economy builds a novel trend for the workplace and for entrepreneurship. Rev Manag Sci 12(1):317-334

Brand M, Tiberius V, Bican PM, Brem A (2021) Agility as an innovation driver: towards an agile front end of innovation framework. Rev Manag Sci 15:157-187

Burdon S, Mooney GR, Al-Kilidar H (2015) Navigating service sector innovation using co-creation partnerships. J Serv Theor Pract 25(3):285-303

Burdon S, Kang K, Mooney G (2017) Decoding success factors of Innovation Culture. In: Tavana M (ed) Enterprise information systems and the digitalization of business functions, IGI Global, pp $258-271$

Cabral L (2012) Living up to expectations: corporate reputation and sustainable competitive advantage. New York University and CEPR

Capdevila I (2013) Typologies of localized spaces of collaborative innovation (SSRN 2414402). SSRN J. https://doi.org/10.2139/ssrn.2414402

Carmines EG, Zeller RA (1979) Reliability and validity assessment, vol 17. Sage Publications, Thousand Oaks

Cegarra-Navarro JG, Reverte C, Gómez-Melero E, Wensley AK (2016) Linking social and economic responsibilities with financial performance: the role of innovation. Eur Manag J 34(5):530-539

Cheah S, Ho YP (2019) Coworking and sustainable business model innovation in young firms. Sustainability 11(10):29-59

Chin WW (1998) The partial least squares approach to structural equation modeling. Modern Methods Bus Res 295(2):295-336

Christensen CM, Raynor ME, Anthony SD (2003) Six keys to creating new-growth businesses. Harv Manag Updat 8(1):3-6

Chun R (2006) Innovation and reputation: An ethical character perspective. Creat Innov Manag 15(1):63-73

Churchill GA Jr (1979) A paradigm for developing better measures of marketing constructs. J Mark Res 16(1):64-73

Clark CE (2000) Differences between public relations and corporate social responsibility: an analysis. Public Relat Rev 26(3):363-380

Clauss T, Bouncken RB, Laudien S, Kraus S (2020) Business model reconfiguration and innovation in SMEs: a mixed-method analysis from the electronics industry. Int J Innov Manag 24(02):2050015

Corazza L, Scagnelli SD, Mio C (2017) Simulacra and sustainability disclosure: Analysis of the interpretative models of creating shared value. Corp Soc Responsib Environ Manag 24(5):414-434 
Cordeiro JJ, Sambharya RB (1997) Part V: Other consequences of corporate reputation: do corporate reputations influence security analyst earnings forecasts? An Empirical Study. Corpor Reput Rev 1(2):94-98

Covin JG, Lumpkin GT (2011) Entrepreneurial orientation theory and research: reflections on a needed construct. Entrep Theory Pract 35(5):855-872

Covin JG, Miller D (2014) International entrepreneurial orientation: conceptual considerations, research themes, measurement issues, and future research directions. Entrep Theory Pract 38(1):11-44

Crane A, Palazzo G, Spence LJ, Matten D (2014) Contesting the value of "creating shared value." Calif Manage Rev 56(2):130-153

Dacin PA, Dacin MT, Matear M (2010) Social entrepreneurship: Why we don't need a new theory and how we move forward from here. Acad Manag Perspect 24(3):37-57

De la Fuente JM, De Quevedo E (2003) Empirical analysis of the relationship between corporate reputation and financial performance: a survey of the literature. Corp Reput Rev 6(2):161-177

De Quevedo PE, De la Fuente Sabaté JM, García JBD (2005) Reputación corporativa y creación de valor. Marco teórico de una relación circular. Investigaciones Europeas de Dirección y Economía de la Empresa 11(2):81-97

Deephouse DL (2000) Media reputation as a strategic resource: An integration of mass communication and resource-based theories. J Manag 26(6):1091-1112

Dembek K, Singh P, Bhakoo V (2016) Literature review of shared value: a theoretical concept or a management buzzword? J Bus Ethics 137(2):231-267

Dulaimi M, Hartmann A (2006) The role of organizational culture in motivating innovative behaviour in construction firms. Constr Innov 6(3):159-172

Dunbar RL, Schwalbach J (2000) Corporate reputation and performance in Germany. Corp Reput Rev 3(2): $115-123$

Eberl M, Schwaiger M (2005) Corporate reputation: disentangling the effects on financial performance. Eur J Market 39:838-854

Fact Sheets on the European Union (2021). https://www.europarl.europa.eu/factsheets/en/home

Fernández-Sánchez JL, Luna-Sotorrío L (2007) The creation of value through corporate reputation. J Bus Ethics 76(3):335-346. https://doi.org/10.1007/s10551-006-9285-0

Flatt SJ, Kowalczyk SJ (2011) Corporate reputation persistence and its diminishing returns. Int J Bus Soc Sci 2(19):1-10

Flavián C, Guinaliu M, Torres E (2005) The influence of corporate image on consumer trust: A comparative analysis in traditional versus internet banking. Intern Res 15:447-470

Florin J, Schmidt E (2011) Creating shared value in the hybrid venture arena: a business model innovation perspective. J Soc Entrepreneur 2(2):165-197

Fornell C, Larcker DF (1981) Evaluating structural equation models with unobservable variables and measurement error. J Mark Res 18(1):39-50

Friedman M (1970) The social responsibility of business is to increase its profits. New York Times Magaz 13:122-126

Fuzi A (2015) Co-working spaces for promoting entrepreneurship in sparse regions: the case of South Wales. Reg Stud Reg Sci 2(1):462-469

Galbreath J, Shum P (2012) Do customer satisfaction and reputation mediate the CSR-FP link? Evidence from Australia. Aust J Manag 37(2):211-229

de los Reyes G Jr, Scholz M, Smith NC (2017) Beyond the "Win-Win" creating shared value requires ethical frameworks. Calif Manag Rev 59(2):142-167

Gatzert N (2015) The impact of corporate reputation and reputation damaging events on financial performance: empirical evidence from the literature. Eur Manag J 33(6):485-499

Gelinas R, Bigras Y (2004) The characteristics and features of SMEs: favorable or unfavorable to logistics integration? J Small Bus Manag 42(3):263-278

Gold AH, Malhotra A, Segars AH (2001) Knowledge management: an organizational capabilities perspective. J Manag Inform Syst 18(1):185-214

Goldberg AI, Cohen G, Feigenbaum A (2003) Reputation building: small business strategies for successful venture development. J Small Bus Manag 41(2):168-186

Greenwood R, Díaz AM, Li SX, Lorente JC (2010) The multiplicity of institutional logics and the heterogeneity of organizational responses. Organ Sci 21(2):521-539

Gregory BT, Harris SG, Armenakis AA, Shook CL (2009) Organizational culture and effectiveness: a study of values, attitudes, and organizational outcomes. J Bus Res 62(7):673-679 
Guo H, Tang J, Su Z, Katz JA (2017) Opportunity recognition and SME performance: the mediating effect of business model innovation. R\&D Manag 47(3):431-442

Hair JF, Black WC, Babin WJ, Anderson RE, Tatham RL (2006) Multivariate data analysis, 6th edn. Pearson Prentice Hall, New Jersey

Hair JF, Ringle CM, Sarstedt M (2011) PLS-SEM: Indeed a silver bullet. J Market Theory Pract 19(2):139-152

Hair JF, Risher JJ, Sarstedt M, Ringle CM (2019) When to use and how to report the results of PLS-SEM. European business review 31(1):2-24. https://doi.org/10.1108/EBR-11-2018-0203

Hall R (1992) The strategic analysis of intangible resources. Strategic Manag J 13:135-144

Halme M, Korpela M (2014) Responsible innovation toward sustainable development in small and medium-sized enterprises: a resource perspective. Bus Strateg Enviro 23(8):547-566

Helm S (2007) The role of corporate reputation in determining investor satisfaction and loyalty. Corp Reput Rev 10(1):22-37

Hemingway CA, Maclagan PW (2004) Managers' personal values as drivers of corporate social responsibility. J Bus Ethics 50(1):33-44

Henseler J, Ringle CM, Sinkovics RR (2009) The use of partial least squares path modeling in international marketing. New challenges to international marketing. Emerald Group Publishing Limited, Bingely

Hirshleifer D, Hsu PH, Li D (2013) Innovative efficiency and stock returns. J Financ Econ 107(3):632-654

Hormiga E, García-Almeida DJ (2016) Accumulated knowledge and innovation as antecedents of reputation in new ventures. J Small Bus Enterp Dev 23(2):428-452

Inglis R, Morley C, Sammut P (2006) Corporate reputation and organisational performance: an Australian study. Manag Audit J 21(9):934-947

Jamali M, Mirshak F (2006) Corporate social responsibility and firm's financial performance. J Acad Manag 31(2):854-872

Jaruzelski B, Loehr J, Holman R (2011) Why culture is key. Strategy Bus 65(1):1-17

Jennings PL, Beaver G (1995) The managerial dimension of small business failure. Strategic Change 4(4):185-200

Jiao Y (2010) Stakeholder welfare and firm value. J Bank Finance 34(10):2549-2561

Jofre-Monseny J (2013) Is agglomeration taxable? J Econ Geogr 13(1):177-201

Jofre-Monseny J, Solé-Ollé A (2010) Tax differentials in intraregional firm location: Evidence from new manufacturing establishments in Spanish municipalities. Reg Stud 44(6):663-677

Jofre-Monseny J, Solé-Ollé A (2012) Which communities should be afraid of mobility? The effects of agglomeration economies on the sensitivity of employment location to local taxes. Reg Sci Urban Econ 42(1-2):257-268

Kaufmann A, Tödtling F (2002) How effective is innovation support for SMEs? An analysis of the region of Upper Austria. Technovation 22(3):147-159

Keizer JA, Dijkstra L, Halman JI (2002) Explaining innovative efforts of SMEs: an exploratory survey among SMEs in the mechanical and electrical engineering sector in The Netherlands. Technovation 22(1):1-13

Khan R (2015) Towards realising social sustainability in the small hydropower sector in India: opportunities for social innovations. Int J Innov Sustain Develop 9:48-62

Kroeger A, Weber C (2014) Developing a conceptual framework for comparing social value creation. Acad Manage Rev 39(4):513-540

Lange D, Lee PM, Dai Y (2011) Organizational reputation: a review. J Manag 37(1):153-184

Lau VMY, Tovstiga G (2015) Exploration of relational factors: Sino-foreign joint venture partnering. J Strateg Manag 8:191-202

Lee DD, Faff RW, Langfield-Smith K (2009) Revisiting the vexing question: does superior corporate social performance lead to improved financial performance? Aust J Manag 34(1):21-49

Lee Y, Shin J, Park Y (2012) The changing pattern of SME's innovativeness through business model globalization. Technol Forecast Soc Chang 79(5):832-842

Leenders MA, Wierema B (2002) The effectiveness of different mechanisms for integrating marketing and R\&D. J Prod Innovat Manag 19(4):305-317

Li W, Sadick MA, Musah AAI, Mustapha S (2018) The moderating effect of social innovation in perspectives of shared value creation in the educational sector of Ghana. Sustainability 10(11):4216

Lichtenthaler U (2017) Shared value innovation: Linking competitiveness and societal goals in the context of digital transformation. Int J Innov Technol Manag 14(04):1750018 
Yeh-Yun Lin C and Yi-Ching Chen M (2007) Does innovation lead to performance? An empirical study of SMEs in Taiwan. Management Research News 30(2):115-132. https://doi. org/10.1108/01409170710722955

Lindgren P (2012) Business model innovation leadership: how do sme's strategically lead business model innovation? Int J Bus Manag 7(14):53-66

López VA, Iglesias S (2010) A reputational--performance framework in an sme context: some empirical evidence from Spain. Irish J Manag 29(2)

López-Pérez ME, Melero I, Javier Sese F (2017) Management for sustainable development and its impact on firm value in the SME context: does size matter? Bus Strateg Environ 26(7):985-999

Lumpkin GT, Dess GG (1996) Enriching the entrepreneurial orientation construct-reply to "entrepreneurial orientation or pioneer advantage.” Acad Manage Rev 21(3):605-607

Málovics G, Csigéné NN, Kraus S (2008) The role of corporate social responsibility in strong sustainability. J Socio-Econ 37(3):907-918

Maranville S (1992) Entrepreneurship in the business curriculum. J Educ Bus 68(1):27-31

Martínez I, Olmedo I (2010) Revisión teórica de la reputación en el entorno empresarial. Cuad Econ Dir Empres 13(44):59-77

Maruf AA (2013) Corporate social responsibility and corporate image. Transnat J Sci Technol 3(8):29-49

McGuire JB, Schneeweis T, Branch B (1990) Perceptions of firm quality: a cause or result of firm performance. J Manag 16(1):167-180

Melé D, Debeljuh P, Arruda MC (2006) Corporate ethical policies in large corporations in Argentina. Brazil Spain J Bus Ethics 63(1):21-38

Miralles-Marcelo JL, Miralles-Quirós MM, Daza-Izquierdo J (2014) Reputación corporativa y creación de valor para el accionista. Universia Bus Rev 44:16-32

Moon HC, Parc J, Yim SH, Park N (2011) An extension of Porter and Kramer's creating shared value (CSV): reorienting strategies and seeking international cooperation. J Int Area Stud 18:49-64

Muethel M (2013) Accepting global leadership responsibility: how leader react to corporate social irresponsibility. Organ Dyn 42:209-216

Muñoz-Pascual L, Curado C, Galende J (2021) How does the use of information technologies affect the adoption of environmental practices in SMEs? a mixed-methods approach. Rev Manag Sci $15: 75-102$

Nanda S, Schneeweis T, Eneroth K (1996) Corporate performance and firm perception: the British experience. Eur Financ Manag 2(2):197-221

Nedungadi P (1990) Recall and consumer consideration sets: influencing choice without altering brand evaluations. J Consum Res 17(3):263-276

Nejati M, Quazi A, Amran A, Ahmad NH (2017) Social responsibility and performance: does strategic orientation matter for small businesses? J Small Bus Manag 55:43-59

Nicholls A, Cho A (2008) Social entrepreneurship: the structuration of a field. In: Nicholls A (ed) Social entrepreneurship: new models of sustainable social change. Oxford University Press, Oxford, pp $99-118$

Obsuwan S, Chandrashekar D, Kraus S, Brem A, Bouncken R (2021) Does cultural diversity matter for team performance in multinational companies? An analysis of conflict, communication, social integration, creativity and satisfaction. Int J Innov Manag 25(07):2150082

OECD (2005) The measurement of scientific and technological activities proposed guidelines for collecting and interpreting technological innovation data. Paris, France

O'Regan N, Ghobadian A (2004) The importance of capabilities for strategic direction and performance. Manag Decis 42:292-312

Orlitzky M, Benjamin JD (2001) Corporate social performance and firm risk: a meta-analytic review. Bus Soc 40(4):369-396

Pekovic S, Vogt S (2021) The fit between corporate social responsibility and corporate governance: the impact on a firm's financial performance. Rev Manag Sci 15(4):1095-1125

Piperopoulos P, Scase R (2009) Competitiveness of small and medium sized enterprises: towards a two dimensional model of innovation and business clusters. Int J Bus Innov Res 3(5):479-499

Porter ME, Kramer MR (2011) Creating shared value. Harv Bus Rev, pp. 62-77

Prahalad CK, Ramaswamy V (2004) Co-creation experiences: the next practice in value creation. J Interact Mark 18(3):5-14

Raithel S, Schwaiger M (2015) The effects of corporate reputation perceptions of the general public on shareholder value. Strategy Manage J 36(6):945-956 
Ramli NA, Latan H, Solovida GT (2019) Determinants of capital structure and firm financial performance-a PLS-SEM approach: evidence from Malaysia and Indonesia. Q Rev Econ Finance 71:148-160

Ramos-González MDM, Rubio-Andrés M, Sastre-Castillo MÁ (2021) Effects of socially responsible human resource management (SR-HRM) on innovation and reputation in entrepreneurial SMEs. Int Entrep Manag J. https://doi.org/10.1007/s11365-020-00720-8

Rasoulzadeh H, Hosseinipour SJ, Yusof NAM, Soltani M, Hashemi S (2013) Effect of dimensions of corporate social responsibility on organization performance. Int J Innov Ideas 13(2):37-47

Rauch A, Wiklund J, Lumpkin GT, Frese M (2009) Entrepreneurial orientation and business performance: an assessment of past research and suggestions for the future. Entrep Theory Pract 33(3):761-787

Rhaiem K, Amara N (2021) Learning from innovation failures: a systematic review of the literature and research agenda. Rev Manag Sci 15(2):189-234

Riahi-Belkaoui A (2004) Relationship between tax compliance internationally and selected determinants of tax morale. J Int Account Audit Tax 13(2):135-143

Rindova VP, Williamson IO, Petkova AP, Sever JM (2005) Being good or being known: an empirical examination of the dimensions, antecedents, and consequences of organizational reputation. Acad Manag J 48(6):1033-1049

Ringle CM, Wende S, Becker JM (2015) SmartPLS 3, SmartPLS GmbH, Bönningstedt

Roberts PW, Dowling GR (1997) The value of a firm's corporate reputation: How reputation helps attain and sustain superior profitability. Corp Reput Rev 1(1):72-76

Roberts PW, Dowling GR (2002) Corporate reputation and sustained superior financial performance. Strateg Manage J 23(12):1077-1093

Rose C, Thomsen S (2004) The impact of corporate reputation on performance: some danish evidence. Eur Manag J 22(2):201-210

Rubio-Andrés M, Ramos-González MDM, Sastre-Castillo MÁ, Danvila-del-Valle I (2020) Exploring sustainability, good governance, and social responsibility in small and medium enterprises. Corp Soc Responsib Environ Manag 27(2):852-869

Saeidi SP, Sofian S, Saeidi P, Saeidi SP, Saaeidi SA (2015) How does corporate social responsibility contribute to firm financial performance? The mediating role of competitive advantage, reputation, and customer satisfaction. J Bus Res 68(2):341-350

Salas Fumás V (2011) Responsabilidad Social Corporativa (RSC) y Creación de Valor Compartido: La RSC según Michael Porter y Mark Kramer. Rev Responsab Soc Empresa 9:15-40

Sánchez-Hernández MI, Bañegil-Palacios TM, Sanguino-Galván R (2017) Competitive success in responsible regional ecosystems: an empirical approach in Spain focused on the firms' relationship with stakeholders. Sustainability 9(3):449

Schnietz KE, Epstein MJ (2005) Exploring the financial value of a reputation for corporate social responsibility during a crisis. Corp Reput Rev 7(4):327-345

Sharma S (2014) Environmental movements and social networking sites in Bangladesh. Int J Innov Sustain Develop 8:380-393

Sinkovics N, Sinkovics RR, Yamin M (2014) The role of social value creation in business model formulation at the bottom of the pyramid-implications for MNEs? Int Bus Rev 23(4):692-707

Sridhar M, Mehta A (2018) The moderating and mediating role of corporate reputation in the link between service innovation and cross-buying intention. Corp Reput Rev 21(2):50-70

Soufre R, Gopalakrishna-Remani V (2019) Management, social sustainability, reputation, and financial performance relationships: an empirical examination of US firms. Organ Environ 32(3):331-362

Staniewski MW, Nowacki R, Awruk K (2016) Entrepreneurship and innovativeness of small and medium-sized construction enterprises. Int Entrep Manag J 12(3):861-877

Swanson LA, Di Zhang D (2010) The social entrepreneurship zone. J Nonprofit Public Sect Mark 22(2):71-88

Szczygielski K, Grabowski W, Woodward R (2017) Innovation and the growth of service companies: the variety of firm activities and industry effects. Ind Innov 24(3):249-262

Thompson JD, MacMillan IC (2010) Business models: creating new markets and societal wealth. Long Range Plan 43(2-3):291-307

Tokoro N (2015) The smart city and the co-creation of value: A source of new competitiveness in a lowcarbon society. Springer, Tokyo

Vaccaro A, Parente R, Veloso FM (2010) Knowledge management tools, inter-organizational relationships, innovation and firm performance. Technol Forecast Soc Chang 77(7):1076-1089 
Valdez-Juárez LE, Gallardo-Vázquez D, Ramos-Escobar EA (2018) CSR and the supply chain: effects on the results of SMEs. Sustainability 10(7):2356

Van Beurden P, Gössling T (2008) The worth of values-a literature review on the relation between corporate social and financial performance. J Bus Ethics 82(2):407

Venâncio A, Barros V, Raposo C (2020) Corporate taxes and high-quality entrepreneurship. Small Bus Econ. https://doi.org/10.1007/s11187-020-00413-0

Wagner M (2010) Corporate social performance and innovation with high social benefits: a quantitative analysis. J Bus Ethics 94(4):581-594

Wang Y, Berens G (2015) The impact of four types of corporate social performance on reputation and financial performance. J Bus Ethics 131(2):337-359

Weerawardena J, Mort GS (2006) Investigating social entrepreneurship: a multidimensional model. J World Bus 41(1):21-35

Weng PS, Chen WY (2017) Doing good or choosing well? Corporate reputation, CEO reputation, and corporate financial performance. N Am Econ Financ 39:223-240

Wu ML (2006) Corporate social performance, corporate financial performance, and firm size: a metaanalysis. J Am Acad Bus 8(1):163-171

Yeh-Yun Lin C, Yi-Ching Chen M (2007) Does innovation lead to performance? An empirical study of SMEs in Taiwan. Manag Res News 30(2):115-132

Zhong X, Ren G, Wu X (2021) Not all stakeholders are created equal: executive vertical pay disparity and firms' choice of internal and external CSR. Rev Manag Sci. https://doi.org/10.1007/ s11846-021-00502-8

Publisher's Note Springer Nature remains neutral with regard to jurisdictional claims in published maps and institutional affiliations.

\section{Authors and Affiliations}

\section{Mercedes Rubio-Andrés ${ }^{1}\left(\mathbb{D} \cdot \mathrm{M}^{\mathrm{a}}\right.$ del Mar Ramos-González ${ }^{2}$ (D) Miguel Ángel Sastre-Castillo ${ }^{3,4} \mathbb{D}$}

Ma del Mar Ramos-González

mariamar.ramosgonzalez@ceu.es

Miguel Ángel Sastre-Castillo

masastre@ucm.es

1 Department of Business Administration, Complutense University of Madrid, Madrid, Spain

2 Department of Business Administration, CEU San Pablo University, Madrid, Spain

3 Complutense University of Madrid, Madrid, Spain

4 ISDI University, Madrid, Spain 